\title{
Novel Vaccination Strategies against Tuberculosis
}

\author{
Peter Andersen ${ }^{1}$ and Stefan H.E. Kaufmann ${ }^{2}$ \\ ${ }^{1}$ Statens Serum Institut, DK-2300 Copenhagen S, Denmark \\ ${ }^{2}$ Max Planck Institute for Infection Biology, 10117 Berlin, Germany \\ Correspondence: pa@ssi.dk
}

The tuberculosis (TB) pandemic continues to rampage despite widespread use of the BCG (Bacillus Calmette-Guérin) vaccine. Novel vaccination strategies are urgently needed to arrest global transmission and prevent the uncontrolled development of multidrug-resistant forms of Mycobacterium tuberculosis. Over the last two decades, considerable progress has been made in the field of vaccine development with numerous innovative preclinical candidates and more than a dozen vaccines in clinical trials. These vaccines are developed either as boosters of the current BCG vaccine or as novel prime vaccines to replace BCG. Given the enormous prevalence of latent TB infection, vaccines that are protective on top of an already established infection remain a high priority and a significant scientific challenge. Here we discuss the current state of TB vaccine research and development, our understanding of the underlying immunology, and the requirements for an efficient TB vaccine.

$V^{2}$ accination is one of the most successful medical measures to reduce morbidity and mortality (Kaufmann 2010). It has liberated us from the threat of numerous infectious diseases including polio, measles, hepatitis $\mathrm{B}$, and smallpox. Increasing accessibility to vaccines of resource-poor regions by the Expanded Program on Immunization (EPI) has reduced child mortality from 20 million in 1960 to less than 10 million in 2005. In 1974, Bacille CalmetteGuérin (BCG) vaccination against tuberculosis (TB) was included in the EPI and now covers $80 \%$ of all infants on this globe. With more than 4 billion administrations, this vaccine has saved many infants' lives by protecting against serious forms of disseminated TB (Hatherill 2011; WHO 2013). Yet, the vaccine has had a minor impact on TB incidences because it fails to protect against the most prevalent form of this disease, pulmonary TB. The World Health Organization (WHO) has proposed to reduce prevalence by half in 2015, as compared to 1990 - a goal that will be largely achieved by currently available intervention measures (Kaufmann et al. 2010; StopTBPartnership and WHO 2011). The more ambitious goal to eliminate TB by 2050, however, can only be accomplished if better diagnostics, drugs, and vaccines become available in due time (Kaufmann et al. 2010; StopTBPartnership and WHO 2011). In-

Editors: Stefan H.E. Kaufmann, Eric J. Rubin, and Alimuddin Zumla

Additional Perspectives on Tuberculosis available at www.perspectivesinmedicine.org

Copyright (C) 2014 Cold Spring Harbor Laboratory Press; all rights reserved; doi: 10.1101/cshperspect.a018523

Cite this article as Cold Spring Harb Perspect Med 2014;4:a018523 
deed, the last decade has witnessed the development of novel vaccine candidates with more than a dozen undergoing clinical assessment (Kaufmann 2011, 2012). Here we describe general principles underlying TB vaccination, and the vaccine candidates that have entered the clinical trial pipeline. We will also discuss chances of success of current vaccine candidates and the need for further research and development to keep the vaccine pipeline viable. It cannot be excluded that vaccine candidates currently in the pipeline will fail, as was the case for the first vaccine candidate who completed a phase IIb efficacy trial without evidence of protection (Tameris et al. 2013) and another candidate who dropped out because of serious adverse events (Kupferschmidt 2011).

\section{BCG, THE CURRENT VACCINE AGAINST TB}

Mycobacterium bovis BCG is the only vaccine currently available against TB, and it has been in use for more than 80 years. The vaccine was developed at the Institute Pasteur, Lille, France, after more than 13 years of continuous in vitro passage of $M$. bovis, the pathogen responsible for TB in cattle (Calmette et al. 1927; Calmette and Plotz 1929). The genetic background for the attenuation of BCG was unknown until advances in molecular biology allowed direct comparisons between the genomes of M. bovis and the various strains of BCG. It became clear that the long-term in vitro propagation had resulted in the loss of several gene segments clustered in different regions of difference (RDs) (Behr et al. 1999). The RD1 is the original mutation resulting in attenuation of M. bovis, and this segment is lacking in all strains of BCG and encodes important virulence factors and T-cell antigens, such as early secretory antigenic $6 \mathrm{kDa}$ (ESAT-6) and culture filtrate protein 10 (CFP10).

The efficacy of BCG was studied extensively in clinical trials during the 1930s and the vaccine was widely deployed after World War II. BCG is one of the most widely administered vaccines worldwide and has been part of the EPI since the early 1970s. BCG vaccination pre- vents disseminated disease (especially military and meningeal TB) in children, but despite inducing a strong $\mathrm{T}$ helper 1 (Th1) response, the efficacy of BCG is highly variable and the vaccine inadequately prevents pulmonary $\mathrm{TB}$ in all age groups, in particular in high-TB-endemic regions. Some of the hypotheses to explain the variable performance of $B C G$ relates to the variation to technical factors of BCG itself (Tolderlund 1952; Janaszek 1991). However, the fact that BCG provides protection against extrapulmonary TB in childhood but not against pulmonary TB in adults suggests that the major problem with BCG is not only its efficacy per se but also waning or changed immune responses in adolescence. The simple explanation is that immunological memory after one vaccination does not last lifelong, and being a live vaccine, BCG is not considered for a secondary booster immunization later in life. The existence of abundant atypical mycobacteria in environmental samples in high-endemic regions adds to the complexity by providing their own level of anti-TB immunity to the population that may mask the effect of BCG or prevent the necessary vaccine replication (the so-called blocking hypothesis) (reviewed in Andersen and Doherty 2005). Although the millions of doses of BCG administered clearly emphasizes that this vaccine is generally safe, the WHO Global Advisory Committee on Vaccine Safety has changed its recommendations to advise against the use of BCG in $\mathrm{HIV}^{+}$children based on reported cases of disseminated BCG disease (Hesseling et al. 2004). This new policy obviously highlights the need for new and safe vaccines for both priming and boosting.

In their early studies on BCG vaccination, Calmette and Guérin already observed that BCG vaccination not only protected infants against death due to $\mathrm{TB}$, but also reduced general mortality in infants who did not suffer from TB disease (Calmette et al. 1927). This topic was largely ignored for decades. More recently, epidemiologic evidence has been presented from several low-income countries that BCG vaccination is correlated with reduced general infant mortality (Roth et al. 2006; Benn et al. 2013). This is an intriguing observation that could in- 
fluence decisions about continuation of BCG, even after licensure of novel vaccine candidates.

\section{IMMUNE EFFECTOR CELLS AND MECHANISMS: WHAT SHOULD A TB VACCINE DO?}

Immunity against $\mathrm{TB}$ is cell-mediated with $\mathrm{T}$ lymphocytes serving as mediators and mononuclear phagocytes as effectors of protection and pathology (Collins and Kaufmann 2001; Ernst 2012; O'Garra et al. 2013). Immunity against TB is a local event focused on granulomatous lesions with solid granulomas reflecting protection and caseous granulomas mirroring disease (Gengenbacher and Kaufmann 2012; Reece and Kaufmann 2012). Immune mechanisms involve CD4 T lymphocytes of Th1 type. These cells produce interferon $\gamma($ IFN- $\gamma)$, which activates increased antimycobacterial activities in macrophages. Although, the central role of this axis in protective immunity against TB is beyond doubt, it has become increasingly clear that it is insufficient (Kaufmann 2013). Other $\mathrm{T}$ lymphocytes, notably CD8 T lymphocytes, and CD4 T cells producing interleukin (IL)-17 (Khader et al. 2007; Cruz et al. 2010), are likely involved in protective immunity (Woodworth and Behar 2006; Ottenhoff 2012). The Th17 cells seem to participate in the initiation of protective immunity. CD8 T cells can contribute to protection by secreting killer molecules (comprising perforin and granulysin, which directly attack macrophages and M. tuberculosis [Mtb], respectively) and by secreting IFN- $\gamma$ (Stenger et al. 1998). Several unconventional T lymphocytes have been proposed to participate in immunity as well including $\gamma \delta \mathrm{T}$ cells and CD1-restricted T cells (Brigl and Brenner 2004; Bonneville and Scotet 2006). Aside from IFN- $\gamma$, other cytokines thought to participate in protection include tumor necrosis factor (TNF), granulocyte-monocyte colony-stimulating factor (GM-CSF), IL-1 $\beta$, and the small molecule, vitamin D (Bermudez and Young 1990; Liu et al. 2006; Fabri et al. 2011). Even though the precise roles of different cells and mediators have not been fully elucidated, it is likely that the cross talk between the different elements has to be highly regulated, both with respect to timing and to location. Uncontrolled hyper- or hyporeactions of any participant of the cross talk can lead to disease reactivation of a previously well-controlled LTBI. Indeed protection and pathology are likely based on similar mechanisms-protection prevails as long as immunity is tightly controlled, whereas pathology develops once this control wanes (Ernst 2012).

Protection and pathology are focused to granulomatous lesions, which are primarily composed of $\mathrm{T}$ lymphocytes, mononuclear phagocytes, dendritic cells (DCs), and B lymphocytes (Gengenbacher and Kaufmann 2012; Reece and Kaufmann 2012). As long as the cellular components control each other, the lesion remains well-structured and contains $M t b$ successfully, even though the pathogen is not eradicated. Disturbances in the granuloma result in exaggerated cell death causing necrosis leading to liquefaction (Gengenbacher and Kaufmann 2012; Reece and Kaufmann 2012). These caseous granulomas not only fail to constrain $M t b$ but rather provide a fertile soil for $M t b$ growth and expansion. The different stages of granulomas need to be viewed within a continuum where the different forms coexist in TB patients (Barry et al. 2009; Gengenbacher and Kaufmann 2012). Thus, in one granuloma of a given patient, $M t b$ may still be contained, whereas in another, it may already have taken over.

Activated macrophages primarily inhibit $M t b$ growth and rarely eradicate the pathogen fully. Growth control is achieved by a combination of reactive oxygen and nitrogen intermediates supported by lysosomal enzyme attack (MacMicking et al. 1997). On the other hand, $M t b$ is capable of interfering with phagosome maturation (Rohde et al. 2007). It arrests the phagosome at an early stage, thus prohibiting fusion with lysosomes containing antibacterial enzymes. Aside from mononuclear phagocytes, neutrophils possess potent antibacterial effector functions (Amulic et al. 2012; Cooper and Torrado 2012). Yet, these short-lived phagocytes also have a high intrinsic risk of causing tissue damage (Kaufmann and Dorhoi 2013).

$M t b$ persisting in macrophages within solid granulomas enter a stage of dormancy in which 
they shut down their replicative and metabolic activity. These dormant $M t b$ express a different gene profile and therefore different antigens that may have a role in vaccines targeting LTBI (Leyten et al. 2006; Andersen 2007). Moreover, dormant $M t b$ are highly resistant to immune attack (Gengenbacher and Kaufmann 2012). The dormant Mtb does not harm the host but resists its elimination. Before TB disease reactivation, $M t b$ undergoes resuscitation, resulting in a highly replicative and metabolically active stage, which is characteristic for active TB disease.

Human TB is a spectral disease depending on the capacity of the immune system to contain $M t b$ in granulomas or not. In ca. 2 billion individuals, LTBI remains lifelong, whereas in almost 9 million individuals, disease develops every year (WHO 2013). It is clear that defined immunosuppressive mechanisms tip the balance in favor of the pathogen. Thus, HIV infection, affecting CD4 $\mathrm{T}$ lymphocytes, is the driving force for the current TB pandemic (UNAIDS and WHO 2013); treatment of patients with chronic inflammation such as rheumatoid arthritis with LTBI causes TB reactivation (Keane et al. 2001; Dixon et al. 2010), and individuals with genetic deficiency in the IFN- $\gamma$ signaling pathways have a heightened risk of TB (Bustamante et al. 2011). Yet, in the majority of cases, the subtle changes, which lead to active disease, remain far from being understood. Better understanding of these mechanisms could provide a blueprint for future vaccine development (Kaufmann 2013). Current vaccine candidates try to mimic the immune response that prevails in LTBI (i.e., stimulation of IFN- $\gamma$-producing CD4 T cells) combined with some activation of Th17 cells, and of CD8 T cells. This strategy anticipates that vaccination can induce a protective immune response in susceptible individuals prone to risk of active TB in a similar way as natural $M t b$ infection does in individuals with lifelong LTBI. Ideally, next-generation vaccines should do better and not only induce containment of $M t b$ but also achieve its eradication (Kaufmann 2013). Prevention of Mtb infection by vaccination would be an alternative strategy (Kaufmann 2013).

\section{LONG-LIVED IMMUNOLOGICAL MEMORY-A DESIRABLE QUALITY FOR A TB VACCINE}

The purpose of vaccination is to establish a long-lived state of immunological memory, and for a chronic infection like LTBI, this is obviously a central goal. The most important obstacle with the current vaccine, BCG, is the lack of protection in adults, which may be related to insufficient immunological memory resulting in waning of immunity during childhood. What do we know about immunological memory against TB? The basic foundation was established in early animal studies that showed that a primary infection cleared by antibiotic treatment provided long-lived immunologic memory immunity, and various levels of increased resistance against secondary infection (Orme 1988; Andersen and Heron 1993; Mollenkopf et al. 2004). Protection was mediated by a CD4 $\mathrm{T}$-cell population that was rapidly recruited to the site of infection, and if the CD4 T-cell subset was purified from memory immune animals, they could adoptively transfer protection against subsequent $\mathrm{TB}$ in recipient mice (Orme and Collins 1984; Andersen and Smedegaard 2000). CD4 T cells are not one homogenous population and can be subdivided based on their anatomical location, expression of various cell surface markers, and cytokine secretion into effector and memory T-cell subsets (Sallusto et al. 2004; Seder et al. 2008). Effector memory $\mathrm{T}$ cells $\left(\mathrm{T}_{\mathrm{em}}\right)$ have low expression of CD62L and CCR7. They are found in peripheral tissues and produce effector cytokines like IFN- $\gamma$ and TNF$\alpha$, often together with IL-2. In their final stage of differentiation, they lose their ability to proliferate and produce IL-2, and at this stage are referred to as terminal or short-lived effector $\mathrm{T}$ cells $\left(\mathrm{T}_{\text {eff }}\right)$. Recent data suggest that for both CD4 and CD8 $\mathrm{T}$ cells, the $\mathrm{T}_{\text {eff }}$ subset can be phenotypically defined by their expression of the killer cell lectin-like receptor G1 (KLGR1) (Joshi et al. 2007; Reiley et al. 2010; Lindenstrom et al. 2013). Central memory $\mathrm{T}$ cells $\left(\mathrm{T}_{\mathrm{cm}}\right)$, are opposite to $\mathrm{T}_{\text {eff }}$ based on most of these fundamental parameters. They are characterized by a high expression of CD62L and CCR7 (which 
direct them through lymph nodes), and produce abundant IL-2 (Sallusto et al. 2004; Seder et al. 2008). The $\mathrm{T}_{\mathrm{cm}}$ subset is of particular importance for the maintenance of immunologic memory after vaccination because of its continuous proliferation, and it was shown by adoptive transfer studies in the TB mouse model to mediate a highly efficient protection in the lung against an aerosol challenge with $M t b$ (Andersen and Smedegaard 2000).

In addition to phenotypic markers, the breakthrough in the definition of T-cell subsets based on their cytokine profile defined by intracellular (IC) flow cytometry (Seder et al. 2008) has resulted in the functional characterization of $\mathrm{T}$ cells based on the expression of different combinations of cytokines. Data from animal models as well as human clinical trials have led to the paradigm that the quality (i.e., protective potential) of $\mathrm{T}$ cells correlates with the number of cytokines coexpressed by the vaccine-promoted CD4 T cells. Moreover, if more than two cytokines are expressed, they are defined as highquality multifunctional $\mathrm{T}$ cells (Darrah et al. 2007). Several independent reports of TB subunit vaccines have correlated enhancement of such multifunctional Th1 cells with growth reduction following aerosol $\mathrm{Mtb}$ infection of mice (Forbes et al. 2008; Derrick et al. 2011). Howev$\mathrm{er}$, for the discussion of these data in relation to immunological memory, the use of the term "multifunctional" can be misleading. For example, in an intracellular cytokine staining (ICS) assay where IFN- $\gamma$, TNF $\alpha$, and IL- 2 coexpression are compared, defining CD4 $\mathrm{T}$ cells with two functions as multifunctional would combine IFN- $\gamma / \mathrm{TNF} \alpha$, IFN- $\gamma / \mathrm{IL}-2$, and TNF $\alpha /$ IL-2 producers. However, IFN- $\gamma / \mathrm{TNF} \alpha$ cells are $T_{\text {eff }}$, whereas $T N F \alpha / I L-2$ cells are $T_{c m}$, and these two subsets have markedly different roles in the maintenance of immunological memory. In comparative studies of an adjuvanted subunit vaccine and BCG, the subunit vaccine very efficiently maintained a population of IL-2 ${ }^{+} \mathrm{T}_{\mathrm{cm}}$ for up to 2 years postvaccination, whereas this population was only transiently expressed after BCG vaccination (Lindenstrom et al. 2009).

This pattern was also seen in chronically infected mice, where mice boosted with the sub- unit vaccine maintained a robust $T_{c m}$ population in the infected organs in contrast to BCGvaccinated animals that were characterized by terminally differentiated effector $\mathrm{T}$ cells and failure to control bacterial replication (Lindenstrom et al. 2013). A lack of long-lived $\mathrm{T}_{\mathrm{cm}}$ may therefore represent one of BCG's major shortcomings (Orme 2010; Lindenstrom et al. 2013). In a recent study of BCG vaccination in humans it was observed that although the T-cell responses had phenotypic markers that resemble $\mathrm{T}_{\mathrm{cm}}$, their cytokine profiles (mostly IFN- $\gamma$ ) and their lack of proliferation had $\mathrm{T}_{\text {eff }}$ characteristics (Soares et al. 2013). That the IL-2 ${ }^{+} \mathrm{T}_{\mathrm{cm}}$ population is of importance for long-term containment of $M t b$ infection in humans is also suggested by a direct comparison of IFN- $\gamma$ and IL-2 release in a modified QuantiFERON test, where IL-2 was characteristic for LTBI in contrast to active TB patients that produced IFN- $\gamma$ only (Biselli et al. 2010). Of importance for the discussion of vaccine-promoted memory, the induction of $\mathrm{T}_{\mathrm{cm}}$ is dependent on both vector/ adjuvant delivery (Billeskov et al. 2013) and vaccine dose (Aagaard et al. 2009). Low doses of antigen in a slow-release vehicle seem to maintain $\mathrm{T}_{\mathrm{cm}}$ and memory responses very efficiently.

\section{HOW CAN WE TARGET TB WITH VACCINES (PRE/POST AND THERAPEUTIC)}

Principally, TB vaccines can be administered at three different stages of infection/disease (Table 1; Fig. 1). Preexposure vaccines are administered prior to infection with $M t b$. The current vaccine $\mathrm{BCG}$, the recombinant $(\mathrm{r})$ viable vaccine candidates, and most subunit vaccines that will be used to boost BCG have been designed as preexposure vaccines (Kaufmann 2012; Frick 2013). The target population is infants, vaccinated soon after birth. BCG is given during the first weeks of life, and whereas the viable vaccine candidates are supposed to replace BCG, the subunit vaccines are considered as boosters of priming with BCG or with a replacement vaccine. Postexposure vaccines target adolescents and adults with LTBI. More recent subunit vaccine candidates have been tailored for this strategy as so-called multistage vaccines by integrat- 


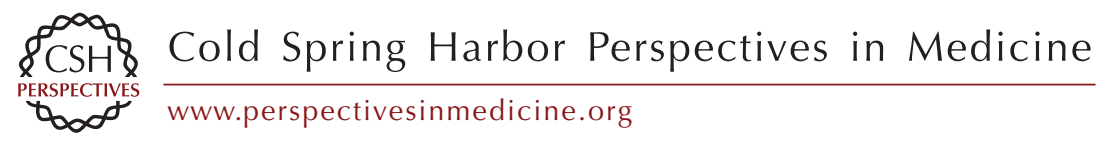

Table 1. Overview of tuberculosis vaccines in clinical trial

\begin{tabular}{|c|c|c|c|c|c|c|c|}
\hline Vaccine name & Target indication & $\begin{array}{l}\text { Antigen name or } \\
\text { Rv number }\end{array}$ & Antigen function & Delivery system & Descriptive notes & Phase & Reference(s) \\
\hline MTBVAC & Preventive & NA & NA & Live mycobacteria & $\begin{array}{l}\text { Attenuated MTB with } \\
\text { two gene deletions }\end{array}$ & I & Arbues et al. 2013 \\
\hline VPM 1002 & Preventive & NA & NA & $\begin{array}{l}\text { Live rBCG strain } \\
\text { expressing } \\
\text { listeriolysin, } \\
\text { urease-deleted }\end{array}$ & $\begin{array}{l}\text { Improved antigenicity } \\
\text { due to perforation of } \\
\text { phagosome } \\
\text { membrane }\end{array}$ & IIa & Grode et al. 2005, 2013 \\
\hline Ad5 Ag85A & Preventive & Ag85A & Mycolyltransferase & Adenovirus 5 vector & $\begin{array}{l}\text { Replication-deficient } \\
\text { viral delivery system }\end{array}$ & I & Smaill et al. 2013 \\
\hline Ad35/MVA85A & Preventive & $\begin{array}{l}\text { Ag85A, Ag85B } \\
\text { TB10.4 }\end{array}$ & $\begin{array}{l}\text { Mycolyltransferase } \\
\text { Virulence factor }\end{array}$ & $\begin{array}{l}\text { Adenovirus } 35 \text { and } \\
\text { modified vaccinia } \\
\text { Ankara vector }\end{array}$ & $\begin{array}{l}\text { Prime boost } \\
\text { combination of two } \\
\text { viral delivery } \\
\text { systems }\end{array}$ & I & $\begin{array}{l}\text { Radosevic et al. 2007; Abel } \\
\text { et al. } 2010\end{array}$ \\
\hline $\begin{array}{l}\text { Ad35/AERAS- } \\
\quad 402\end{array}$ & Preventive & $\begin{array}{l}\text { Ag85A, Ag85B } \\
\text { TB10.4 }\end{array}$ & $\begin{array}{l}\text { Mycolyltransferase } \\
\text { Virulence factor }\end{array}$ & $\begin{array}{l}\text { Adenovirus } 35 \\
\quad \text { vector }+ \\
\text { modified vaccinia } \\
\text { Ankara virus }\end{array}$ & $\begin{array}{l}\text { Replication-deficient } \\
\text { viral delivery system }\end{array}$ & IIa & $\begin{array}{l}\text { Radosevic et al. 2007; Abel } \\
\text { et al. } 2010\end{array}$ \\
\hline H4/IC31 & Preventive & $\begin{array}{l}\text { Ag85B } \\
\text { TB10.4 }\end{array}$ & $\begin{array}{l}\text { Mycolyltransferase } \\
\text { Virulence factor }\end{array}$ & IC31 & $\begin{array}{l}\text { Formulation of } \\
\text { cationic peptide and } \\
\text { a synthetic TLR-9 } \\
\text { agonist }\end{array}$ & IIa & $\begin{array}{l}\text { Dietrich et al. 2005; } \\
\text { Aagaard et al. 2009; } \\
\text { Billeskov et al. } 2012\end{array}$ \\
\hline MVA85A & Preventive & Ag85A & Mycolyltransferase & $\begin{array}{l}\text { Modified vaccinia } \\
\text { Ankara }\end{array}$ & $\begin{array}{l}\text { Replication-deficient } \\
\text { viral delivery system }\end{array}$ & IIb & $\begin{array}{l}\text { McShane et al. 2004; } \\
\text { Beveridge et al. 2007; } \\
\text { Verreck et al. 2009; } \\
\text { Tameris et al. 2013; } \\
\text { White et al. } 2013\end{array}$ \\
\hline M72 & $\begin{array}{l}\text { Preventive; } \\
\text { postexposure }\end{array}$ & $\begin{array}{l}\text { Rv1196 } \\
\text { Rv0125 }\end{array}$ & $\begin{array}{l}\text { PPE family protein } \\
\text { Peptidase }\end{array}$ & AS01E & $\begin{array}{l}\text { Liposomes } \\
\text { incorporating the } \\
\text { TLR-4 agonist MPL }\end{array}$ & IIa & $\begin{array}{l}\text { Reed et al. 2009; Day et al. } \\
\text { 2013; Leroux-Roels } \\
\text { et al. } 2013\end{array}$ \\
\hline ID93 & $\begin{array}{l}\text { Preventive/ } \\
\text { Postexposure/ } \\
\text { Therapeutic }\end{array}$ & $\begin{array}{l}\text { Rv2608 } \\
\text { Rv3619, Rv3620 } \\
\text { Rv1813 }\end{array}$ & $\begin{array}{l}\text { PPE family protein } \\
\text { Virulence factor } \\
\text { Latency-associated } \\
\text { protein }\end{array}$ & GLA-SE & $\begin{array}{l}\text { Synthetic TLR-4 } \\
\text { agonist in oil-in- } \\
\text { water emulsion }\end{array}$ & I & $\begin{array}{l}\text { Bertholet et al. 2010; Coler } \\
\text { et al. } 2013\end{array}$ \\
\hline
\end{tabular}




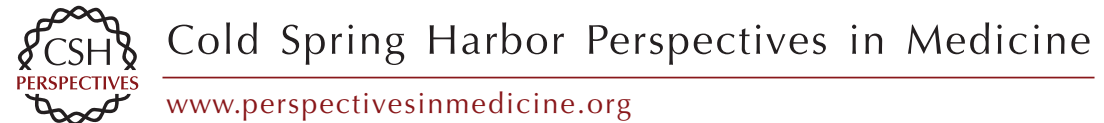

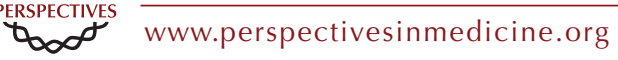

Table 1. Continued

\begin{tabular}{|c|c|c|c|c|c|c|c|}
\hline Vaccine name & Target indication & $\begin{array}{l}\text { Antigen name or } \\
\text { Rv number }\end{array}$ & Antigen function & Delivery system & Descriptive notes & Phase & Reference(s) \\
\hline $\mathrm{H} 1 / \mathrm{H} 56 / \mathrm{IC} 31$ & $\begin{array}{l}\text { Preventive/ } \\
\text { Postexposure/ } \\
\text { Therapeutic }\end{array}$ & $\begin{array}{l}\text { Ag85B } \\
\text { ESAT-6 } \\
\text { Rv2660c }\end{array}$ & $\begin{array}{l}\text { Mycolyltransferase } \\
\text { Virulence factor } \\
\text { Latency-associated } \\
\text { protein }\end{array}$ & IC31 & $\begin{array}{l}\text { Formulation of } \\
\text { cationic peptide and } \\
\text { a synthetic TLR-9 } \\
\text { agonist }\end{array}$ & IIa & $\begin{array}{l}\text { Weinrich Olsen et al. 2001; } \\
\text { van Dissel et al. 2010; } \\
\text { Aagaard et al. } 2011\end{array}$ \\
\hline RUTI & Therapeutic & $\mathrm{N} / \mathrm{A}$ & $\mathrm{N} / \mathrm{A}$ & $\begin{array}{l}\text { Whole fragmented } \\
\text { Mtb }\end{array}$ & & I & Cardona 2006 \\
\hline $\begin{array}{l}\text { Mycobacterium } \\
\text { vaccae }\end{array}$ & Therapeutic & $\mathrm{N} / \mathrm{A}$ & $\mathrm{N} / \mathrm{A}$ & $\begin{array}{l}\text { Whole killed } \\
\text { mycobacteria }\end{array}$ & & III & $\begin{array}{l}\text { deBruyn and Garner 2010; } \\
\text { von Reyn et al. 2010; } \\
\text { Yang et al. } 2011\end{array}$ \\
\hline $\begin{array}{l}\text { Mycobacterium } \\
\text { indicus pranii }\end{array}$ & Therapeutic & $\mathrm{N} / \mathrm{A}$ & $\mathrm{N} / \mathrm{A}$ & $\begin{array}{l}\text { Whole killed } \\
\text { mycobacteria }\end{array}$ & & III & Gupta et al. 2012a \\
\hline
\end{tabular}

NA, not applicable. 


\section{P. Andersen and S.H.E. Kaufmann}

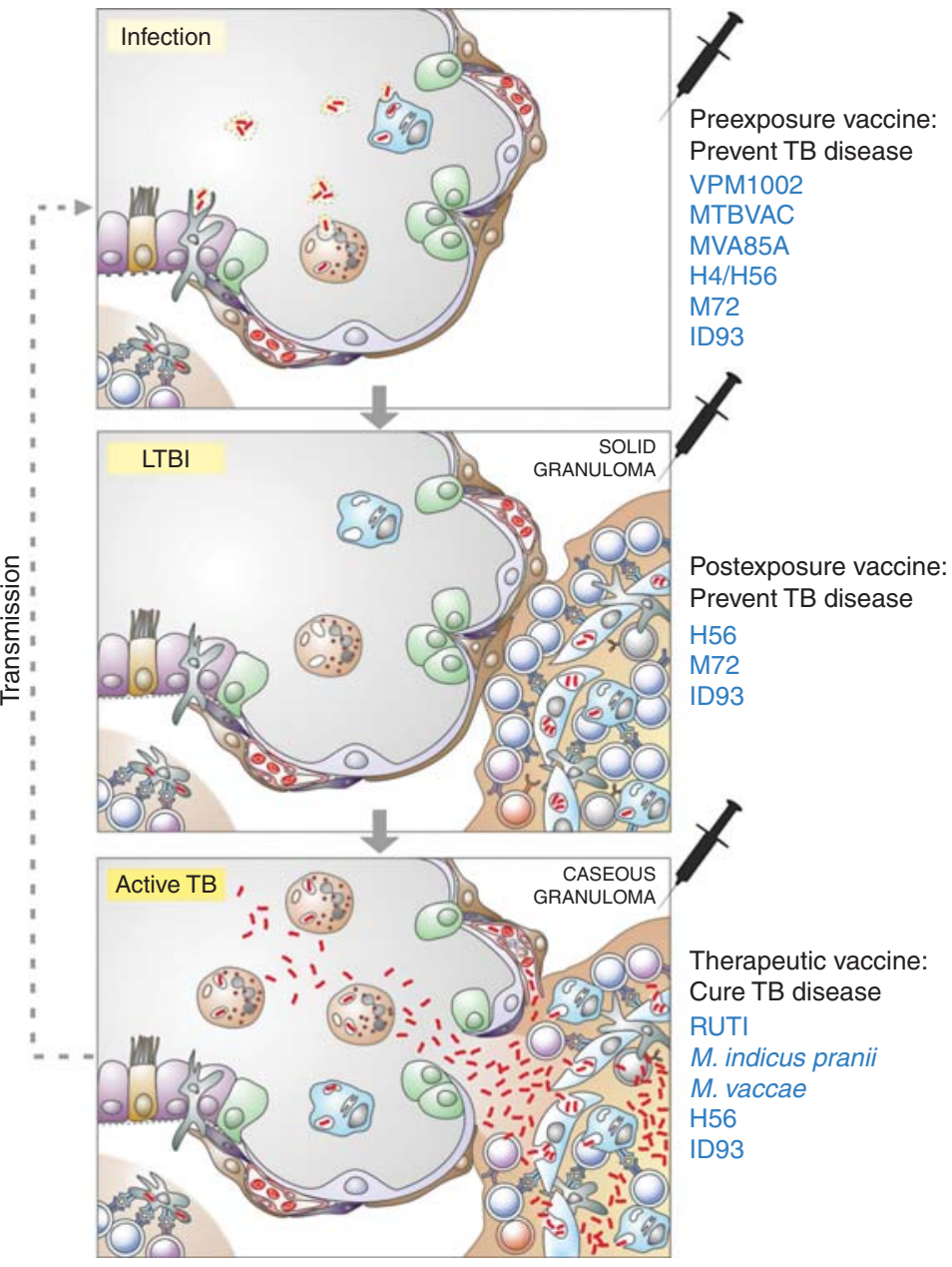

Figure 1. Novel vaccination strategies in the context of tuberculosis (TB) immunology and pathology. The three stages of TB are shown: infection, latent TB infection (LTBI), and active TB. Soon after Mycobacterium tuberculosis $(\mathrm{Mtb})$ has entered a lung alveolus, it will be taken up by alveolar macrophages (blue) and neutrophils (orange) in the alveolar space and dendritic cells interspersed in the epithelial layer. These dendritic cells transport $M t b$ into draining lymph nodes where acquired immunity is stimulated. During LTBI solid granulomas contain $M t b$ inside mononuclear phagocytes. These solid granulomas are highly structured under the orchestration of T lymphocytes. During active TB, granulomas deteriorate and become caseous. As a consequence, $M t b$ multiplies in an unrestricted way and is spread through capillaries to other organs and through ruptures into the alveolar space, to the environment. Preexposure vaccines $(t o p)$ to prevent TB disease are given before infection. VPM1002 and MTBVAC are live replacement vaccines given for prime instead of BCG and MVA85A; H4/H56, ID93, and M72 are booster vaccines on top of BCG. MVA85A is viral-vectored, whereas H4/ H56, ID93 and M72 are protein adjuvant formulations; the target population is infants. Postexposure vaccines (middle) to prevent TB disease are given during LTBI as booster of a BCG prime. H56, M72, and ID93 are protein adjuvant formulations; the target population is adolescents and adults. Therapeutic vaccines (bottom) are given to patients with active TB in adjunct to or following chemotherapy, to cure TB or to prevent recurrence. RUTI is a semipurified preparation of $M t b$, and Mycobacterium indicus pranii and Mycobacterium vaccae are killed preparations of atypical mycobacteria; the target population is TB patients, notably coinfected with HIV and/or suffering from multidrug or extensively drug-resistant TB. 
ing latency antigens of Mtb (Andersen 2007) (see Table 1, Fig 1). Again, these vaccines are considered as booster vaccines of BCG (or BCG replacement) prime given at infancy. Therapeutic vaccines target patients with active TB in adjunct to (and to shorten) chemotherapy or patients suffering from extensively or totally drug-resistant (XDR and TDR, respectively) TB (Frick 2013; Prabowo et al. 2013). A candidate of this type is a killed Mycobacterium vaccae preparation that was used to treat patients with HIV coinfection suffering from miliary $\mathrm{TB}$, with ambiguous outcome (von Reyn et al. 2010). Another M. vaccae vaccine has also failed to prove therapeutic benefit (deBruyn and Garner 2010; Yang et al. 2011; Frick 2013). RUTI, a semipurified preparation of killed $M t b$, has completed phase II assessment in HIV-infected and -uninfected individuals with LTBI (Cardona 2006). Killed Mycobacterium indicus pranii was originally designed as vaccine against leprosy but found to have potential effects against TB. This vaccine has been licensed in India and is currently undergoing clinical phase III testing for TB treatment (Gupta et al. 2012a,b). In the following we will focus on preventive vaccines.

\section{LIVE VACCINES}

Currently, two types of live vaccines are under clinical assessment, an rBCG and an rMtb deletion mutant (Grode et al. 2005; Arbues et al. 2013; Grode et al. 2013). The rBCG VPM1002 (rBCG $\Delta$ UreC::hly) expresses listeriolysin (hly) from Listeria monocytogenes. Moreover, the urease $\mathrm{C}$ (ureC) gene was deleted in this construct. The absence of ureC allows stronger acidification of the phagosome in which VPM1002 resides. The more acidic $\mathrm{pH}$ in turn provides the optimum for biological activity of hly, a membraneperforating molecule (Palmer 2001). Perforation allows egression of rBCG-derived antigens into the cytosol resulting in apoptosis of macrophages harboring the vaccine. These two alterations likely cause improved immunogenicity of the vaccine. Moreover, hly is only active at acidic $\mathrm{pH}$ and contains a PEST sequence comprised of proline $(\mathrm{P})$, glutamate $(\mathrm{E})$, serine $(\mathrm{S})$, and threonine $(\mathrm{T})$, which induces rapid aggregation and degradation of this molecule in the cytosol (Decatur and Portnoy 2000). These two features contribute to the safety of the vaccine candidate. VPM1002 has successfully passed two phase I trials and completed the direct observational stage of a phase IIa trial, in infants in South Africa (Grode et al. 2013; Kaufmann et al. 2014). The other live vaccine candidate MTBVAC is a double-deletion mutant of $M t b$ with deleted PhoP and FadD26 (Arbues et al. 2013). PhoP acts as a transcription factor in $M t b$, which covers a broad range of some 80 genes, many of which are involved in virulence. Because of the request by WHO that $M t b$-based live vaccine should comprise at least two mutations (Walker et al. 2010), FadD26, which encodes a critical enzymes in the biosynthesis of phthiocerol dimycocerosates, was deleted in addition. This vaccine is currently undergoing a phase I trial (Arbues et al. 2013).

\section{SUBUNIT VACCINES}

The first successful attempts to develop a nonviable subunit vaccine against $\mathrm{TB}$ were based on complex culture filtrate preparations, and these vaccines were found by several groups to impart considerable protection in various animal models (reviewed in Andersen 1994). Subunit vaccines for boosting BCG-induced responses can be divided into adjuvanted recombinant proteins or viral vector systems. Both strategies depend on the induction of immune responses to a single or a few antigens that are immunodominant during infection.

\section{Viral Vectors}

Viral vectors are replication-deficient variants of virus that, in their virulent form, are pathogens for humans or closely related nonhuman primates. Vaccinia and adenovirus are the most clinically advanced and both have proved immunogenic for boosting BCG responses in clinical trials (McShane et al. 2004; Abel et al. 2010). Both adenovirus and vaccinia virus are potent mucosal vaccines that give improved protection when administered through the mucosal route compared to conventional parenteral routes 
(Goonetilleke et al. 2003; Wang et al. 2004; White et al. 2013).

The modified vaccinia virus Ankara expressing Ag85A (MVA85A) was the first novel BCG booster vaccine to reach the stage of clinical testing and evaluated to be safe and immunogenic in naïve healthy individuals and in volunteers vaccinated with BCG (McShane et al. 2004). In terms of immunogenicity, MVA85A markedly boosted the preexisting BCG-induced immune responses and promoted strong boosting of IFN- $\gamma$ measured by ELISPOT and polyfunctional immune responses (Beveridge et al. 2007). Since these initial promising results, a very ambitious clinical program that culminated with the first efficacy trial of a novel vaccine since BCG was developed (Tameris et al. 2013). In this trial, 2797 BCG-vaccinated infants were enrolled, and although MVA85A was found to induce immune responses with a similar profile as in previous studies, the magnitude of responses in infants was more modest. Using a series of end points for TB disease and a QuantiFERON conversion as a measure of $M t b$-infection, the efficacy of MVA85A against TB was $17.3 \%$ ( -31.9 to 48.2$)$ and against infection $-3.8 \%$ ( -28.1 to 15.9$)$, showing no evidence of protection against TB disease or $M t b$ infection (Tameris et al. 2013). When discussing lessons learned from this trial, it is important to bear in mind that MVA85A may simply have been unable to improve on the protection provided by BCG in infants, where BCG provides its best protection (which is, however, still insufficient to eliminate the TB in children). In this regard the clinical data from the MVA85A trial are in agreement with the modest and nonsignificant added value when this vaccine was evaluated as a BCG booster in nonhuman primates (Verreck et al. 2009; Beverley 2013). The vaccine is currently under evaluation in a phase IIb clinical trial in $\mathrm{HIV}^{+}$adults. Independent of the underlying reason for the failure, the trial can provide valuable insights when the immune data are scrutinized in greater detail and correlated with clinical outcome.

Replication-deficient adenoviral systems have either used Ad5 or Ad35 platforms. The replication-deficient Ad35 vector expressing
Ag85A, Ag85B, and TB10.4 (AERAS-402) (Radosevic et al. 2007) was chosen to avoid preexisting and neutralizing antibody responses often found with Ad, but to which extent such antibodies represent a real problem for vaccine take is questioned by recent data that found no evidence that preexisting immunity significantly dampened the potency of an Ad5-based TB vaccine in a clinical phase I trial (at least over the duration of the trial) (Smaill et al. 2013). Adenovirus-based vaccines differ from the majority of the other vaccines by inducing an immune response biased toward the induction of CD8 $\mathrm{T}$ cells observed in both preclinical studies as well as in BCG-vaccinated adults in South Africa (Radosevic et al. 2007; Abel et al. 2010). However, the extent to which adenovirus promoted CD8 epitopes are available for recognition during natural $M t b$ infection and involved in protective immunity is the subject of ongoing debate (Bennekov et al. 2006; Elvang et al. 2009). The AERAS-402 vaccine is currently undergoing clinical phase IIa, but has in addition recently entered clinical trials in prime-boost combinations with MVA85A. The negative outcome of the STEP trial (where a recombinant adenovirus increased the risk of HIV/AIDS) (News in Brief 2007), however, makes it questionable if an adenovirus-based vaccine will ever be recommended for widespread use in the areas of the globe where Mtb and HIV coexist.

\section{Adjuvanted Vaccines}

When the first fusion proteins ( $\mathrm{H} 1$ from SSI and M72 from GSK) were ready for clinical testing, only alum and MF59 were approved for human use, and both of these adjuvants are known to induce antibodies exclusively and have very limited protective potential in $\mathrm{TB}$ vaccines (Doherty and Andersen 2005). This has recently changed and today we have several novel adjuvant formulations in clinical trials (Table 1). Significant progress has been made in the construction and testing of recombinant proteins, mostly fusion proteins that combine two or more immunodominant antigens of $M t b$. The first fusion protein-based vaccine was the Hybrid 1 (H1) fusion protein which consists of 
Ag85B fused to ESAT-6 (Weinrich Olsen et al. 2001). This molecule has been tested with various adjuvants and has been taken into clinical trials formulated in the IC31 adjuvant, which activates human Toll-like receptor (TLR)9, facilitates antigen uptake by DCs and provides a slow release depot (Lingnau et al. 2007). IC31 stimulates robust IFN- $\gamma$ production by CD4 Th1 cells in humans and its most striking feature is its ability to maintain long-lasting memory immune responses still detectable $2.5 \mathrm{yr}$ after the last vaccination (van Dissel et al. 2010). The H1 fusion protein in IC31 adjuvant is currently in a phase IIa trial. A novel molecule, H56, based on the H1 backbone but incorporating the late-stage $\mathrm{Rv} 2660 \mathrm{c}$ antigen (combined into a so-called multistage vaccine-see below) is currently in clinical phase I and may take over the role of $\mathrm{H} 1$ as the leading subunit vaccine for adolescent boost (Aagaard et al. 2011). Another polyprotein called H4 consists of Ag85B fused to the antigen TB10.4 (which in contrast to ESAT-6 is expressed also by BCG) (Dietrich et al. 2005; Billeskov et al. 2012) and is developed by Sanofi in a parallel clinical development program (Table 1). Both the H1/ $\mathrm{H} 56$ and $\mathrm{H} 4$ fusion molecules have (in addition to the IC31 adjuvant) been extensively evaluated in preclinical animal models together with the CAF01 adjuvant (Weinrich Olsen et al. 2001; Lindenstrom et al. 2009). This liposome-based formulation combines the cationic surfactant dimethyldioctadecylammonium (DDC) with trehalose-dibehenate (TDB), a synthetic analog of the mycobacterial cord factor. This adjuvant signals through the innate immune receptor monocyte-inducible C-type lectin (Mincle) and has strong adjuvant properties comprising long-lived memory Th1 and Th17 responses (Lindenstrom et al. 2009, 2012; Desel et al. 2013) in adult as well as in neonatal mice (Kamath et al. 2009). The CAF01 adjuvant combined with the $\mathrm{H} 1$ molecule has recently successfully completed a clinical phase I trial.

The M72 fusion protein, consisting of $M t b$ antigens Rv1196 and Rv0125 originally developed as a collaboration between Corixa and GSK, has been successfully evaluated in various preclinical models including nonhuman pri- mates (Reed et al. 2009). A phase I/II trial comparing the adjuvants AS01 (monophosphoryl lipid A [MPL] combined with the saponin derivative QS21 in liposomes) and AS02 (based on the same components in an oil-in-water emulsion) identified the liposomal formulation as the most immunogenic form in terms of inducing a CD4 T-cell response and led to the selection of AS01 for further clinical development in high endemic regions (Day et al. 2013; LerouxRoels et al. 2013). Currently, a multicenter phase IIb trial involving vaccination of adults in the 18- to 50-yr age range is projected to start in early 2014.

The most recent $\mathrm{TB}$ vaccine entering clinical trial is ID93 from the Infectious Disease Research Institute (IDRI) (Bertholet et al. 2010). This vaccine combines a novel set of antigens (Rv2608, Rv3619, Rv3620, and Rv1813) not previously tested in humans and synthetic MPL formulated in a glucopyranosyl lipid stable emulsion (GLA-SE) and is designed to target both active and latent TB. In preclinical studies, this vaccine was protective almost at BCG levels in mice and the combination of BCG with an ID93 booster was able to reduce mortality in guinea pigs compared to BCG alone (Bertholet et al. 2010). In nonhuman primates the administration of ID93 on top of conventional anti-TB treatment reduced the lung pathology associated with disease (Coler et al. 2013). In an ongoing phase I trial, the safety and immunogenicity will be tested in healthy adults.

\section{VACCINES AGAINST LATENT TB}

An estimated 2 billion individuals are already infected with $M t b$; they represent a huge reservoir for disease reactivation. With a reactivation rate of $\sim 5 \%-10 \%$, this is an incredible number of people who are at risk of developing TB disease and can infect other individuals. Thus, preventing latently infected individuals from reactivating disease is a high priority for any novel TB vaccination strategy. Mathematical modeling has shown that the most effective way to accelerate the global control of TB is a conventional preexposure vaccine combined with an efficient postexposure vaccine (Abu-Raddad 
et al. 2009). A late BCG booster (to be given to adolescents) will frequently be administered postexposure because of the high prevalence of latent TB in this age group. Over the years there has been much debate on safety of a postexposure vaccine strategy, stimulated by the original failure (and death of several patients) of Koch's tuberculin as a therapeutic vaccine (Guttstadt 1891; Kaufmann and Winau 2005).

However, based on both animal data and recent clinical data there is so far no evidence to support this theoretical concern. Vaccination with 12 different vaccine preparations in a lowbacterial-burden mouse model developed to reflect LTBI did not induce any reactivation or worsening of pathology (Derrick et al. 2008), and by now several of the new experimental vaccines have been in clinical trials in individuals with LTBI with no apparent safety problem (Scriba et al. 2012; Day et al. 2013; Grode et al. 2013). Yet, there are still significant scientific challenges to overcome before an efficient post-exposure vaccine to prevent $\mathrm{TB}$ reactivation has become a reality. As $M t b$ adapts to the conditions in the immune host, the current data suggest that the bacteria transform from a growing metabolically active state to nonreplicating persistence with low metabolic activity (Andersen 2007; Barry et al. 2009; Gengenbacher and Kaufmann 2012; Reece and Kaufmann 2012). In this process the bacteria change their gene expression profile, which results in a different or modified antigenic repertoire where, for example, the genes encoding the Ag85 family are down-regulated to very low levels (Shi et al. 2004; Bold et al. 2011; Aagaard et al. 2011; Commandeur et al. 2013). The changed antigen repertoire has been confirmed in human studies showing that the antigens preferentially recognized by the immune system in latently infected healthy individuals differed from patients with active TB disease (Demissie et al. 2006; Leyten et al. 2006; Schuck et al. 2009). Mimicking conditions thought to reflect the environment inside the granuloma in vitro and evaluating the transcriptional response has thus been the subject of intensive research in recent years. The antigens under consideration are (i) DosR regulon and the enduring hypoxic response- - both sets of overlapping genes are up-regulated in response to hypoxia (Park et al. 2003; Rustad et al. 2008); (ii) starvation antigens-up-regulated by $M t b$ upon depletion of nutrients (Betts et al. 2002); and (iii) resuscitation antigens that are produced as the bacteria resumes growth (Gupta et al. 2010; Commandeur et al. 2011). Addition of late-stage antigens to the well-established prophylactic vaccines may provide the basis for multistage $\mathrm{TB}$ vaccines with activity against all stages of infection (Andersen 2007). A multistage vaccine (H56) that combined the H1 (Ag85B ESAT-6) backbone and the $M t b$ starvation/latency antigen Rv2660c induced superior protection against late-stage infection in the mouse model of long-term persistent TB (Aagaard et al. 2011). The vaccine also prevented TB reactivation in a nonhuman primate model where animals received immunosuppressive anti-TNF treatment (Lin et al. 2012). The role of Rv2660 in the improved protection promoted by the $\mathrm{H} 56$ vaccine is the subject of ongoing evaluation. The antigen encoded by this gene is recognized in individuals with LTBI (Govender et al. 2010), and strong responses are found after TB challenge in nonhuman primates (Lin et al. 2012). The protein was identified in a high-resolution proteomic analysis of BCG (Zheng et al. 2012), but a recent strand-specific PCR analysis suggests that the gene is not translated into a protein in the $M t b$ strains analyzed (Houghton et al. 2013). It is therefore presently not clear if the Rv2660c gene product mediates its beneficial influence on the H56 molecule directly as an antigen or has an indirect influence of the overall immune profile of the $\mathrm{H} 56$ polyprotein fusion. A phase I clinical trial of $\mathrm{H} 56$ has just been completed and an ongoing phase IIa trial will optimize the dose of H56 in individuals with LTBI in South Africa.

The ID93 vaccine, which incorporates the latency-associated antigen encoded by Rv1813, was recently tested in TB-infected nonhuman primates in combination with conventional chemotherapy and this treatment was shown to reduce the duration of treatment compared with chemotherapy alone (Coler et al. 2013). Other recent studies have taken the same approach and combined different classes of anti- 
gens into fusion molecules or cocktails delivered in adjuvants. In a study by Jeon and colleagues, a vaccine based on the early antigen Ag85A was compared to the late antigen HspX (Jeon et al. 2011). Whereas the vaccine based on Ag85A protected best at day 30, the HspX-based vaccine gave the best protection at $90 \mathrm{~d}$ and the combination protected at both time points. Reece and Kaufmann (2012) expressed three different late antigens (Rv3407, Rv1733c, and Rv2659c) in rBCG (VPM1002 backbone). Also in this study, a characteristic feature was an improved late-stage protection with improved survival after $200 \mathrm{~d}$.

A recent study evaluated the potential of ESAT- 6 and the closely related antigen TB10.4 $(\mathrm{EsxH})$ as components in preventive and postexposure TB vaccines (Hoang et al. 2013). In this study four different fusion-protein vaccines were constructed that only differed in these two components, and whereas all vaccines induced protection in a conventional prophylactic vaccination model, only the ESAT-6 containing vaccines had an effect when administered postexposure. The vaccine effect was influenced by the infectious load at the time point of vaccination and abolished in chronically infected animals with high bacterial loads at the onset of vaccination (Hoang et al. 2013). The findings are in agreement with a previous observation of postexposure activity of ESAT-6 containing vaccines in the guinea pig model measured both by growth and pathology (Henao-Tamayo et al. 2009). In this study the vaccines were administered once on top of early acute infection, which may explain that only a transient effect with no impact on long-term survival was seen. Therefore, although enhancing immunity to TB in animal models after exposure to $M t b$ infection has proved difficult, there are still grounds for optimism.

\section{CONCLUDING REMARKS}

With more than a dozen vaccine candidates moving forward in the clinical trial pipeline, comprising replacement vaccines for prime and subunit vaccines for boost, vaccines for pre- and postexposure with $M t b$, as well as TB therapy, a broad TB portfolio has been developed. Yet, most of the current vaccine candidates induce immune responses qualitatively similar to those operative in healthy individuals with LTBI. The question remains whether this will suffice to achieve TB elimination by 2050 as claimed by the StopTB Partnership of the WHO (StopTBPartnership and WHO 2011). The most likely scenario is that this first generation of vaccines will be succeeded by a second generation of further improved vaccines. Design of these second-generation vaccines can benefit from information generated in ongoing clinical trials about mechanisms underlying protection. Biomarker studies, notably global gene expression profiling, therefore need to become an essential part of such vaccine trials (Maertzdorf et al. 2012; Weiner et al. 2013; Weiner and Kaufmann 2014). Longitudinal studies monitoring healthy contacts of patients with active TB, who do or do not develop active TB disease, can add valuable information. The disappointing outcome of the MVA85A phase IIb vaccine trial has stimulated new and innovative ideas on a number of aspects of TB vaccine development. First of all, there is now ongoing discussion and planning of future trials to enable the early monitoring of signs of vaccine efficacy. Some of the ideas that are currently being discussed build on either the conversion of the diagnostic IFN- $\gamma$ release assay (the QuantiFERON test) as an indicator of ongoing infection (Andersen et al. 2007) or the prevention of recurrence of disease by vaccination of TB patients following completed chemotherapy. If successful, these designs may allow a very cost-effective and accelerated identification of promising vaccine candidates.

The need to go beyond the most popular antigens in TB vaccine, such as the Ag85 cognates, is also the subject of renewed interest, and recent discovery efforts have provided a number of very promising protective antigens selected to provide target molecules stably expressed also in LTBI (Bertholet et al. 2010; Aagaard et al. 2011; Knudsen et al. 2014), a phase where Ag85-based vaccines may have their limitations because gene expression is shut down (Shi et al. 2004; Bold et al. 2011; Aagaard et al. 2011; Commandeur et al. 2013). 
Finally, the fact that the MVA85A throughout the preclinical and clinical development program was optimized to promote powerful Th1 responses has reemphasized that we need to look broader (and beyond IFN- $\gamma$ ), in our optimization of novel vaccines. Studies in both animal models and human clinical trials have shown that the IFN- $\gamma$ response to BCG vaccination is not predictive of subsequent protection from TB (Elias et al. 2005; Mittrucker et al. 2007; Kagina et al. 2010), and recent data suggest that instead of boosting "more of the same" Th1 response it may be better to promote responses that are insufficiently promoted by BCG and mediated by $\mathrm{T}$ cells devoid of or low in IFN- $\gamma$ expression (Goldsack and Kirman 2007; Lindenstrom et al. 2013).

As we gain access to the expanded data sets from the multiparametric analyses of ongoing and planned proof-of-concept phase IIb clinical trials of the candidate vaccines under evaluation, they will hopefully provide the conceptual basis for the optimal design of vaccines targeting a pathogen that has refined its survival strategy for at least 6000 years.

\section{ACKNOWLEDGMENTS}

We thank Mary Louise Grossman and Christina Gry Paulsen for help preparing the manuscript and Diane Schad for preparing the figure. S.H.E.K. and P.A. are supported by the European Union's Seventh Framework Programme (EU FP7), ADITEC (HEALTH-F4-2011-280873), and NEWTBVAC (HEALTH-F3-2009-241745); the Bill \& Melinda Gates Foundation Grand Challenges in Global Health Program (BMGF GC6-74, \#37772 and GC12, \#37885; GC6-2013 \#OPP 1055806, GC6-2013 \#OPP 1065330); and the Innovative Medicines Initiative (IMI) Joint Undertaking "Biomarkers for Enhanced Vaccine Safety" BIOVACSAFE (IMI JU Grant No. 115308).

\section{REFERENCES}

Aagaard C, Hoang TT, Izzo A, Billeskov R, Troudt J, Arnett K, Keyser A, Elvang T, Andersen P, Dietrich J. 2009. Protection and polyfunctional $\mathrm{T}$ cells induced by Ag85B-
TB10.4/IC31 against Mycobacterium tuberculosis is highly dependent on the antigen dose. PLoS ONE 4: e5930.

Aagaard C, Hoang T, Dietrich J, Cardona PJ, Izzo A, Dolganov G, Schoolnik GK, Cassidy JP, Billeskov R, Andersen P. 2011. A multistage tuberculosis vaccine that confers efficient protection before and after exposure. Nat Med 17: 189-194.

Abel B, Tameris M, Mansoor N, Gelderbloem S, Hughes J, Abrahams D, Makhethe L, Erasmus M, deKock M, vanderMerwe L, et al. 2010. The novel tuberculosis vaccine, AERAS-402, induces robust and polyfunctional $\mathrm{CD}^{+}$ and $\mathrm{CD}^{+} \mathrm{T}$ cells in adults. Am J Respir Crit Care Med 181: 1407-1417.

Abu-Raddad LJ, Sabatelli L, Achterberg JT, Sugimoto JD, Longini IM Jr, Dye C, Halloran ME. 2009. Epidemiological benefits of more-effective tuberculosis vaccines, drugs, and diagnostics. Proc Natl Acad Sci 106: 1398013985.

Amulic B, Cazalet C, Hayes GL, Metzler KD, Zychlinsky A. 2012. Neutrophil function: From mechanisms to disease. Annu Rev Immunol 30: 459-489.

Andersen P. 1994. The T cell response to secreted antigens of Mycobacterium tuberculosis. Immunobiology 191: 537547.

Andersen P. 2007. Vaccine strategies against latent tuberculosis infection. Trends Microbiol 15: 7-13.

Andersen P, Doherty TM. 2005. The success and failure of BCG-Implications for a novel tuberculosis vaccine. Nat Rev Microbiol 3: 656-662.

Andersen P, Heron I. 1993. Specificity of a protective memory immune response against Mycobacterium tuberculosis. Infect Immun 61: 844-851.

Andersen P, Smedegaard B. 2000. CD4 ${ }^{+}$T-cell subsets that mediate immunological memory to Mycobacterium tuberculosis infection in mice. Infect Immun 68: 621-629.

Andersen P, Doherty TM, Pai M, Weldingh K. 2007. The prognosis of latent tuberculosis: Can disease be predicted? Trends Mol Med 13: 175-182.

Arbues A, Aguilo JI, Gonzalo-Asensio J, Marinova D, Uranga S, Puentes E, Fernandez C, Parra A, Cardona PJ, Vilaplana C, et al. 2013. Construction, characterization and preclinical evaluation of MTBVAC, the first live-attenuated M. tuberculosis-based vaccine to enter clinical trials. Vaccine 31: 4867-4873.

Barry CE 3rd, Boshoff HI, Dartois V, Dick T, Ehrt S, Flynn J, Schnappinger D, Wilkinson RJ, Young D. 2009. The spectrum of latent tuberculosis: Rethinking the biology and intervention strategies. Nat Rev Microbiol 7: 845-855.

Behr MA, Wilson MA, Gill WP, Salamon H, Schoolnik GK, Rane S, Small PM. 1999. Comparative genomics of BCG vaccines by whole-genome DNA microarray. Science 284: $1520-1523$.

Benn CS, Netea MG, Selin LK, Aaby P. 2013. A small jab-A big effect: Nonspecific immunomodulation by vaccines. Trends Immunol 34: 431-439.

Bennekov T, Dietrich J, Rosenkrands I, Stryhn A, Doherty TM, Andersen P. 2006. Alteration of epitope recognition pattern in Ag85B and ESAT-6 has a profound influence on vaccine-induced protection against Mycobacterium tuberculosis. Eur J Immunol 36: 3346-3355. 
Bermudez LE, Young LS. 1990. Recombinant granulocyteMacrophage colony-stimulating factor activates human macrophages to inhibit growth or kill Mycobacterium avium complex. J Leukoc Biol 48: 67-73.

Bertholet S, Ireton GC, Ordway DJ, Windish HP, Pine SO, Kahn M, Phan T, Orme IM, Vedvick TS, Baldwin SL, et al. 2010. A defined tuberculosis vaccine candidate boosts BCG and protects against multidrug-resistant Mycobacterium tuberculosis. Sci Transl Med 2: 53ra74.

Betts JC, Lukey PT, Robb LC, McAdam RA, Duncan K. 2002. Evaluation of a nutrient starvation model of Mycobacterium tuberculosis persistence by gene and protein expression profiling. Mol Microbiol 43: 717-731.

Beveridge NE, Price DA, Casazza JP, Pathan AA, Sander CR, Asher TE, Ambrozak DR, Precopio ML, Scheinberg P, Alder NC, et al. 2007. Immunisation with BCG and recombinant MVA85A induces long-lasting, polyfunctional Mycobacterium tuberculosis-specific $\mathrm{CD} 4^{+}$memory T lymphocyte populations. Eur J Immunol 37: 30893100.

Beverley P. 2013. TB vaccine failure was predictable. Nature 503: 469.

Billeskov R, Elvang TT, Andersen PL, Dietrich J. 2012. The HyVac4 subunit vaccine efficiently boosts BCG-primed anti-mycobacterial protective immunity. PLOS ONE 7: e39909.

Billeskov R, Christensen JP, Aagaard C, Andersen P, Dietrich J. 2013. Comparing adjuvanted $\mathrm{H} 28$ and modified vaccinia virus ankara expressing $\mathrm{H} 28$ in a mouse and a nonhuman primate tuberculosis model. PLOS ONE 8: e72185.

Biselli R, Mariotti S, Sargentini V, Sauzullo I, Lastilla M, Mengoni F, Vanini V, Girardi E, Goletti D, D’Amelio R, et al. 2010. Detection of interleukin-2 in addition to interferon- $\gamma$ discriminates active tuberculosis patients, latently infected individuals, and controls. Clin Microbiol Infect 16: 1282-1284.

Bold TD, Banaei N, Wolf AJ, Ernst JD. 2011. Suboptimal activation of antigen-specific $\mathrm{CD} 4^{+}$effector cells enables persistence of M. tuberculosis in vivo. PLoS Pathog 7: e1002063.

Bonneville M, Scotet E. 2006. Human V $\gamma 9$ V $\delta 2$ T cells: Promising new leads for immunotherapy of infections and tumors. Curr Opin Immunol 18: 539-546.

Brigl M, Brenner MB. 2004. CD1: Antigen presentation and T cell function. Annu Rev Immunol 22: 817-890.

Bustamante J, Picard C, Boisson-Dupuis S, Abel L, Casanova JL. 2011. Genetic lessons learned from X-linked Mendelian susceptibility to mycobacterial diseases. Ann NY Acad Sci 1246: 92-101.

Calmette A, Plotz H. 1929. Protective inoculation against tuberculosis with BCG. Am Rev Tuberc 19: 567-572.

Calmette A, Guérin C, Boquet A, Négre L. 1927. La vaccination préventive contre la tuberculose par le "BCG". Masson, Paris.

Cardona PJ. 2006. RUTI: A new chance to shorten the treatment of latent tuberculosis infection. Tuberculosis (Edinburgh) 86: 273-289.

Coler RN, Bertholet S, Pine SO, Orr MT, Reese V, Windish HP, Davis C, Kahn M, Baldwin SL, Reed SG. 2013. Therapeutic immunization against Mycobacterium tuberculo- sis is an effective adjunct to antibiotic treatment. J Infect Dis 207: 1242-1252.

Collins HL, Kaufmann SH. 2001. Prospects for better tuberculosis vaccines. Lancet Infect Dis 1: 21-28.

Commandeur S, vanMeijgaarden KE, Lin MY, Franken KL, Friggen AH, Drijfhout JW, Oftung F, Korsvold GE, Geluk A, Ottenhoff TH. 2011. Identification of human T-cell responses to Mycobacterium tuberculosis resuscitationpromoting factors in long-term latently infected individuals. Clin Vaccine Immunol 18: 676-683.

Commandeur S, vanMeijgaarden KE, Prins C, Pichugin AV, Dijkman K, vandenEeden SJ, Friggen AH, Franken KL, Dolganov G, Kramnik I, Schoolnik GK, et al. 2013. An unbiased genome-wide Mycobacterium tuberculosis gene expression approach to discover antigens targeted by human $\mathrm{T}$ cells expressed during pulmonary infection. J Immunol 190: 1659-1671.

Cooper AM, Torrado E. 2012. Protection versus pathology in tuberculosis: Recent insights. Curr Opin Immunol 24: 431-437.

Cruz A, Fraga AG, Fountain JJ, Rangel-Moreno J, Torrado E, Saraiva M, Pereira DR, Randall TD, Pedrosa J, Cooper $\mathrm{AM}$, et al. 2010. Pathological role of interleukin 17 in mice subjected to repeated BCG vaccination after infection with Mycobacterium tuberculosis. J Exp Med 207: 1609-1616.

Darrah PA, Patel DT, DeLuca PM, Lindsay RW, Davey DF Flynn BJ, Hoff ST, Andersen P, Reed SG, Morris SL, et al 2007. Multifunctional $\mathrm{T}_{\mathrm{H}} 1$ cells define a correlate of vaccine-mediated protection against Leishmania major. Nat Med 13: 843-850.

Day CL, Tameris M, Mansoor N, vanRooyen M, deKock M, Geldenhuys H, Erasmus M, Makhethe L, Hughes EJ, Gelderbloem S, et al. 2013. Induction and regulation of Tcell immunity by the novel tuberculosis vaccine M72/ AS01 in South African adults. Am J Respir Crit Care Med 188: 492-502.

deBruyn G, Garner P. 2010. Mycobacterium vaccae immunotherapy for treating tuberculosis. The Cochrane Library 1: $1-17$.

Decatur AL, Portnoy DA. 2000. A PEST-like sequence in listeriolysin O essential for Listeria monocytogenes pathogenicity. Science 290: 992-995.

Demissie A, Leyten EM, Abebe M, Wassie L, Aseffa A, Abate G, Fletcher H, Owiafe P, Hill PC, Brookes R, et al. 2006. Recognition of stage-specific mycobacterial antigens differentiates between acute and latent infections with $M y$ cobacterium tuberculosis. Clin Vaccine Immunol 13: 179_ 186.

Derrick SC, Perera LP, Dheenadhayalan V, Yang A, Kolibab K, Morris SL. 2008. The safety of post-exposure vaccination of mice infected with Mycobacterium tuberculosis. Vaccine 26: 6092-6098.

Derrick SC, Yabe IM, Yang A, Morris SL. 2011. Vaccineinduced anti-tuberculosis protective immunity in mice correlates with the magnitude and quality of multifunctional CD4 T cells. Vaccine 29: 2902-2909.

Desel C, Werninghaus K, Ritter M, Jozefowski K, Wenzel J, Russkamp N, Schleicher U, Christensen D, Wirtz S, Kirschning C, et al. 2013. The Mincle-activating adjuvant TDB induces MyD88-dependent Th1 and Th17 responses through IL-1R signaling. PLoS ONE 8: e53531. 
P. Andersen and S.H.E. Kaufmann

Dietrich J, Aagaard C, Leah R, Olsen AW, Stryhn A, Doherty TM, Andersen P. 2005. Exchanging ESAT6 with TB10.4 in an Ag85B fusion molecule-based tuberculosis subunit vaccine: Efficient protection and ESAT6-based sensitive monitoring of vaccine efficacy. J Immunol 174: 63326339.

Dixon WG, Hyrich KL, Watson KD, Lunt M, Galloway J, Ustianowski A, Symmons DP. 2010. Drug-specific risk of tuberculosis in patients with rheumatoid arthritis treated with anti-TNF therapy: Results from the British Society for Rheumatology Biologics Register (BSRBR). Ann Rheum Dis 69: 522-528.

Doherty TM, Andersen P. 2005. Vaccines for tuberculosis: Novel concepts and recent progress. Clin Microbiol Rev 18: $687-702$.

Elias D, Akuffo H, Britton S. 2005. PPD induced in vitro interferon $\gamma$ production is not a reliable correlate of protection against Mycobacterium tuberculosis. Trans $R$ Soc Trop Med Hyg 99: 363-368.

Elvang T, Christensen JP, Billeskov R, Thi Kim Thanh Hoang T, Holst P, Thomsen AR, Andersen P, Dietrich J. 2009. CD4 and CD8 T cell responses to the M. tuberculosis Ag85B-TB10.4 promoted by adjuvanted subunit, adenovector or heterologous prime boost vaccination. PLoS ONE 4: e5139.

Ernst JD. 2012. The immunological life cycle of tuberculosis. Nat Rev Immunol 12: 581-591.

Fabri M, Stenger S, Shin DM, Yuk JM, Liu PT, Realegeno S, Lee HM, Krutzik SR, Schenk M, Sieling PA, et al. 2011. Vitamin $\mathrm{D}$ is required for IFN- $\boldsymbol{\gamma}$-mediated antimicrobial activity of human macrophages. Sci Transl Med 3: $104 \mathrm{ra} 102$.

Forbes EK, Sander C, Ronan EO, McShane H, Hill AV, Beverley PC, Tchilian EZ. 2008. Multifunctional, high-level cytokine-producing Th1 cells in the lung, but not spleen, correlate with protection against Mycobacterium tuberculosis aerosol challenge in mice. I Immunol 181: 49554964.

Frick M. 2013. Where are we going, where have we been? In The HIV, HCV, TB pipeline report, pp. 263-283. http:// www.pipelinereport.org.

Gengenbacher M, Kaufmann SH. 2012. Mycobacterium tuberculosis: Success through dormancy. FEMS Microbiol Rev 36: 514-532.

Goldsack L, Kirman JR. 2007. Half-truths and selective memory: Interferon $\gamma, \mathrm{CD}^{+} \mathrm{T}$ cells and protective memory against tuberculosis. Tuberculosis (Edinburgh) 87: $465-473$.

Goonetilleke NP, McShane H, Hannan CM, Anderson RJ, Brookes RH, Hill AV. 2003. Enhanced immunogenicity and protective efficacy against Mycobacterium tuberculosis of bacille Calmette-Guérin vaccine using mucosal administration and boosting with a recombinant modified vaccinia virus Ankara. J Immunol 171: 1602-1609.

Govender L, Abel B, Hughes EJ, Scriba TJ, Kagina BM, deKock M, Walzl G, Black G, Rosenkrands I, Hussey GD, et al. 2010. Higher human CD4 T cell response to novel Mycobacterium tuberculosis latency associated antigen Rv2660 and Rv2659 in latent infection compared with tuberculosis disease. Vaccine 29: 51-57.

Grode L, Seiler P, Baumann S, Hess J, Brinkmann V, NasserEddine A, Mann P, Goosmann C, Bandermann S, Smith
D, et al. 2005. Increased vaccine efficacy against tuberculosis of recombinant Mycobacterium bovis bacille Calmette-Guérin mutants that secrete listeriolysin. J Clin Invest 115: 2472-2479.

Grode L, Ganoza CA, Brohm C, Weiner J III, Eisele B, Kaufmann SH. 2013. Safety and immunogenicity of the recombinant BCG vaccine VPM1002 in a phase 1 openlabel randomized clinical trial. Vaccine 31: 1340-1348.

Gupta RK, Srivastava BS, Srivastava R. 2010. Comparative expression analysis of rpf-like genes of Mycobacterium tuberculosis $\mathrm{H} 37 \mathrm{Rv}$ under different physiological stress and growth conditions. Microbiology 156: 2714-2722.

Gupta A, Ahmad FJ, Ahmad F, Gupta UD, Natarajan M, Katoch V, Bhaskar S. 2012a. Efficacy of Mycobacterium indicus pranii immunotherapy as an adjunct to chemotherapy for tuberculosis and underlying immune responses in the lung. PLoS ONE 7: e39215.

Gupta A, Ahmad FJ, Ahmad F, Gupta UD, Natarajan M, Katoch VM, Bhaskar S. 2012b. Protective efficacy of $M y$ cobacterium indicus pranii against tuberculosis and underlying local lung immune responses in guinea pig model. Vaccine 30: 6198-6209.

Guttstadt A. 1891. Die Wirksamkeit des Koch'schen Heilmittels gegen Tuberculose. Springer, Berlin (in German).

Hatherill M. 2011. Prospects for elimination of childhood tuberculosis: The role of new vaccines. Arch Dis Child 96: 851-856.

Henao-Tamayo M, Palaniswamy GS, Smith EE, Shanley CA, Wang B, Orme IM, Basaraba RJ, DuTeau NM, Ordway D. 2009. Post-exposure vaccination against Mycobacterium tuberculosis. Tuberculosis (Edinburgh) 89: 142-148.

Hesseling AC, Schaaf HS, Victor T, Beyers N, Marais BJ, Cotton MF, Wiid I, Gie RP, van Helden P, Warren RM. 2004. Resistant Mycobacterium bovis bacillus CalmetteGuérin disease: Implications for management of bacillus Calmette-Guérin disease in human immunodeficiency virus-infected children. Pediatr Infect Dis J 23: 476-479.

Hoang T, Aagaard C, Dietrich J, Cassidy JP, Dolganov G, Schoolnik GK, Lundberg CV, Agger EM, Andersen P. 2013. ESAT-6 (EsxA) and TB10.4 (EsxH) based vaccines for pre- and post-exposure tuberculosis vaccination. PLoS ONE 8: e80579.

Houghton J, Cortes T, Schubert O, Rose G, Rodgers A, De Ste Croix M, Aebersold R, Young DB, Arnvig KB 2013. A small RNA encoded in the Rv2660c locus of Mycobacterium tuberculosis is induced during starvation and infection. PLOS ONE 8: e80047.

Janaszek W. 1991. Evaluation of thermostability of lyophilized BCG vaccines by using an accelerated thermal degradation test. Med Dosw Mikrobiol 43: 43-49.

Jeon BY, Kim SC, Eum SY, Cho SN. 2011. The immunity and protective effects of antigen $85 \mathrm{~A}$ and heat-shock protein $\mathrm{X}$ against progressive tuberculosis. Microbes Infect 13: 284-290.

Joshi NS, Cui W, Chandele A, Lee HK, Urso DR, Hagman J, Gapin L, Kaech SM. 2007. Inflammation directs memory precursor and short-lived effector $\mathrm{CD} 8^{+} \mathrm{T}$ cell fates via the graded expression of T-bet transcription factor. $\mathrm{Im}$ munity 27: 281-295.

Kagina BM, Abel B, Scriba TJ, Hughes EJ, Keyser A, Soares A, Gamieldien H, Sidibana M, Hatherill M, Gelderbloem S, et al. 2010. Specific T cell frequency and cytokine expres- 
sion profile do not correlate with protection against tuberculosis after bacillus Calmette-Guérin vaccination of newborns. Am J Respir Crit Care Med 182: 1073-1079.

Kamath AT, Rochat AF, Christensen D, Agger EM, Andersen P, Lambert PH, Siegrist CA. 2009. A liposome-based mycobacterial vaccine induces potent adult and neonatal multifunctional $\mathrm{T}$ cells through the exquisite targeting of dendritic cells. PLoS ONE 4: e5771.

Kaufmann SHE. 2010. The new plagues-Pandemics and poverty in a globalized world. Haus Publishing Limited, London.

Kaufmann SH. 2011. Fact and fiction in tuberculosis vaccine research: 10 years later. Lancet Infect Dis 11: 633-640.

Kaufmann SH. 2012. Tuberculosis vaccine development: Strength lies in tenacity. Trends Immunol 33: 373-379.

Kaufmann SH. 2013. Tuberculosis vaccines: Time to think about the next generation. Semin Immunol 25: 172-181.

Kaufmann SH, Dorhoi A. 2013. Inflammation in tuberculosis: Interactions, imbalances and interventions. Curr Opin Immunol 25: 441-449.

Kaufmann SH, Winau F. 2005. From bacteriology to immunology: The dualism of specificity. Nat Immunol 6: 1063-1066.

Kaufmann SH, Hussey G, Lambert PH. 2010. New vaccines for tuberculosis. Lancet 375: 2110-2119.

Kaufmann SH, Cotton MF, Eisele B, Gengenbacher M, Grode L, Hesseling AC, Waltzl G. 2014. The BCG replacement vaccine VPM1002: From drawing board to clinical trail. Expert Rev Vaccines 13: 619-630.

Keane J, Gershon S, Wise RP, Mirabile-Levens E, Kasznica J, Schwieterman WD, Siegel JN, Braun MM. 2001. Tuberculosis associated with infliximab, a tumor necrosis factor $\alpha$-neutralizing agent. N Engl J Med 345: 1098-1104.

Khader SA, Bell GK, Pearl JE, Fountain JJ, Rangel-Moreno J, Cilley GE, Shen F, Eaton SM, Gaffen SL, Swain SL, et al. 2007. IL-23 and IL-17 in the establishment of protective pulmonary $\mathrm{CD}^{+} \mathrm{T}$ cell responses after vaccination and during Mycobacterium tuberculosis challenge. Nat Immunol 8: $369-377$.

Knudsen NP, Norskov-Lauritsen S, Dolganov GM, Schoolnik GK, Lindenstrom T, Andersen P, Agger EM, Aagaard C. 2014. Tuberculosis vaccine with high predicted population coverage and compatibility with modern diagnostics. Proc Natl Acad Sci 111: 1096-1101.

Kupferschmidt K. 2011. Infectious disease. Taking a new shot at a TB vaccine. Science 334: 1488-1490.

Leroux-Roels I, Forgus S, DeBoever F, Clement F, Demoitie MA, Mettens P, Moris P, Ledent E, Leroux-Roels G, OforiAnyinam O, et al. 2013. Improved $\mathrm{CD}^{+}{ }^{+} \mathrm{T}$ cell responses to Mycobacterium tuberculosis in PPD-negative adults by M72/AS01 as compared to the M72/AS02 and Mtb72F/ AS02 tuberculosis candidate vaccine formulations: A randomized trial. Vaccine 31: 2196-2206.

Leyten EM, Lin MY, Franken KL, Friggen AH, Prins C, van Meijgaarden KE, Voskuil MI, Weldingh K, Andersen P, Schoolnik GK, et al. 2006. Human T-cell responses to 25 novel antigens encoded by genes of the dormancy regulon of Mycobacterium tuberculosis. Microbes Infect 8: 2052-2060.

Lin PL, Dietrich J, Tan E, Abalos RM, Burgos J, Bigbee C, Bigbee M, Milk L, Gideon HP, Rodgers M, et al. 2012. The multistage vaccine $\mathrm{H} 56$ boosts the effects of BCG to protect cynomolgus macaques against active tuberculosis and reactivation of latent Mycobacterium tuberculosis infection. J Clin Invest 122: 303-314.

Lindenstrom T, Agger EM, Korsholm KS, Darrah PA, Aagaard C, Seder RA, Rosenkrands I, Andersen P. 2009. Tuberculosis subunit vaccination provides long-term protective immunity characterized by multifunctional CD4 memory T cells. J Immunol 182: 8047-8055.

Lindenstrom T, Woodworth J, Dietrich J, Aagaard C, Andersen P, Agger EM. 2012. Vaccine-induced Th17 cells are maintained long-term postvaccination as a distinct and phenotypically stable memory subset. Infect Immun 80: 3533-3544.

Lindenstrom T, Knudsen NP, Agger EM, Andersen P. 2013. Control of chronic mycobacterium tuberculosis infection by CD4 KLRG1 ${ }^{-}$IL-2-secreting central memory cells. $J$ Immunol 190: 6311-6319.

Lingnau K, Riedl K, von Gabain A. 2007. IC31 and IC30, novel types of vaccine adjuvant based on peptide delivery systems. Expert Rev Vaccines 6: 741-746.

Liu PT, Stenger S, Li H, Wenzel L, Tan BH, Krutzik SR, Ochoa MT, Schauber J, Wu K, Meinken C, et al. 2006. Toll-like receptor triggering of a vitamin D-mediated human antimicrobial response. Science 311: 1770-1773.

MacMicking J, Xie QW, Nathan C. 1997. Nitric oxide and macrophage function. Annu Rev Immunol 15: 323-350.

Maertzdorf J, Weiner J III, Kaufmann SH. 2012. Enabling biomarkers for tuberculosis control. Int J Tuberc Lung Dis 16: $1140-1148$.

McShane H, Pathan AA, Sander CR, Keating SM, Gilbert SC, Huygen K, Fletcher HA, Hill AV. 2004. Recombinant modified vaccinia virus Ankara expressing antigen $85 \mathrm{~A}$ boosts BCG-primed and naturally acquired antimycobacterial immunity in humans. Nat Med 10: 1240-1244.

Mittrucker HW, Steinhoff U, Kohler A, Krause M, Lazar D, Mex P, Miekley D, Kaufmann SH. 2007. Poor correlation between BCG vaccination-induced T cell responses and protection against tuberculosis. Proc Natl Acad Sci 104: 12434-12439.

Mollenkopf HJ, Kursar M, Kaufmann SH. 2004. Immune response to postprimary tuberculosis in mice: Mycobacterium tuberculosis and Mycobacterium bovis bacille Calmette-Guérin induce equal protection. J Infect Dis 190: $588-597$.

News in Brief. 2007. HIV vaccine failure prompts Merck to halt trial. Nature 449: 390

O'Garra A, Redford PS, McNab FW, Bloom CI, Wilkinson RJ, Berry MP. 2013. The immune response in tuberculosis. Annu Rev Immunol 31: 475-527.

Orme IM. 1988. Characteristics and specificity of acquired immunologic memory to Mycobacterium tuberculosis infection. J Immunol 140: 3589-3593.

Orme IM. 2010. The Achilles heel of BCG. Tuberculosis (Edinburgh) 90: 329-332.

Orme IM, Collins FM. 1984. Adoptive protection of the Mycobacterium tuberculosis-infected lung. Dissociation between cells that passively transfer protective immunity and those that transfer delayed-type hypersensitivity to tuberculin. Cell Immunol 84: 113-120. 
P. Andersen and S.H.E. Kaufmann

Ottenhoff TH. 2012. New pathways of protective and pathological host defense to mycobacteria. Trends Microbiol 20: $419-428$.

Palmer M. 2001. The family of thiol-activated, cholesterolbinding cytolysins. Toxicon 39: 1681-1689.

Park HD, Guinn KM, Harrell MI, Liao R, Voskuil MI, Tompa M, Schoolnik GK, Sherman DR. 2003. $\mathrm{Rv} 3133 \mathrm{c} / \mathrm{dos} \mathrm{R}$ is a transcription factor that mediates the hypoxic response of Mycobacterium tuberculosis. Mol Microbiol 48: 833-843.

Prabowo SA, Groschel MI, Schmidt ED, Skrahina A, Mihaescu T, Hasturk S, Mitrofanov R, Pimkina E, Visontai I, deJong B, et al. 2013. Targeting multidrug-resistant tuberculosis (MDR-TB) by therapeutic vaccines. Med Microbiol Immunol 202: 95-104.

Radosevic K, Wieland CW, Rodriguez A, Weverling GJ, Mintardjo R, Gillissen G, Vogels R, Skeiky YA, Hone DM, Sadoff JC, et al. 2007. Protective immune responses to a recombinant adenovirus type 35 tuberculosis vaccine in two mouse strains: CD4 and CD8 T-cell epitope mapping and role of $\gamma$ interferon. Infect Immun 75: 41054115 .

Reece ST, Kaufmann SH. 2012. Floating between the poles of pathology and protection: Can we pin down the granuloma in tuberculosis? Curr Opin Microbiol 15: 63-70.

Reed SG, Coler RN, Dalemans W, Tan EV, DeLaCruz EC, Basaraba RJ, Orme IM, Skeiky YA, Alderson MR, Cowgill $\mathrm{KD}$, et al. 2009. Defined tuberculosis vaccine, Mtb72F/ AS02A, evidence of protection in cynomolgus monkeys. Proc Natl Acad Sci 106: 2301-2306.

Reiley WW, Shafiani S, Wittmer ST, Tucker-Heard G, Moon JJ, Jenkins MK, Urdahl KB, Winslow GM, Woodland DL. 2010. Distinct functions of antigen-specific CD4 T cells during murine Mycobacterium tuberculosis infection. Proc Natl Acad Sci 107: 19408-19413.

Rohde K, Yates RM, Purdy GE, Russell DG. 2007. Mycobacterium tuberculosis and the environment within the phagosome. Immunol Rev 219: 37-54.

Roth A, Garly ML, Jensen H, Nielsen J, Aaby P. 2006. Bacillus Calmette-Guérin vaccination and infant mortality. $E x$ pert Rev Vaccines 5: 277-293.

Rustad TR, Harrell MI, Liao R, Sherman DR. 2008. The enduring hypoxic response of Mycobacterium tuberculosis. PLoS ONE 3: e1502.

Sallusto F, Geginat J, Lanzavecchia A. 2004. Central memory and effector memory T cell subsets: Function, generation, and maintenance. Annu Rev Immunol 22: 745-763.

Schuck SD, Mueller H, Kunitz F, Neher A, Hoffmann H, Franken KL, Repsilber D, Ottenhoff TH, Kaufmann SH, Jacobsen M. 2009. Identification of T-cell antigens specific for latent Mycobacterium tuberculosis infection. PLoS ONE 4: e5590.

Scriba TJ, Tameris M, Smit E, van der Merwe L, Hughes EJ, Kadira B, Mauff K, Brittain N, Lawrie A, Mulenga $\mathrm{H}$, et al. 2012. A phase IIa trial of the new tuberculosis vaccine, MVA85A, in HIV- and/or Mycobacterium tuberculosis-infected adults. Am J Respir Crit Care Med 185: 769-778.

Seder RA, Darrah PA, Roederer M. 2008. T-cell quality in memory and protection: Implications for vaccine design. Nat Rev Immunol 8: 247-258.
Shi L, North R, Gennaro ML. 2004. Effect of growth state on transcription levels of genes encoding major secreted antigens of Mycobacterium tuberculosis in the mouse lung. Infect Immun 72: 2420-2424.

Smaill F, Jeyanathan M, Smieja M, Medina MF, ThanthrigeDon N, Zganiacz A, Yin C, Heriazon A, Damjanovic D, Puri L, et al. 2013. A human type 5 adenovirus-based tuberculosis vaccine induces robust $\mathrm{T}$ cell responses in humans despite preexisting anti-adenovirus immunity. Sci Transl Med 5: 205ra134.

Soares AP, KwongChung CK, Choice T, Hughes EJ, Jacobs G, van Rensburg EJ, Khomba G, deKock M, Lerumo L, Makhethe L, et al. 2013. Longitudinal changes in $\mathrm{CD}^{+} \mathrm{T}$ cell memory responses induced by BCG vaccination of newborns. J Infect Dis 207: 1084-1094.

Stenger S, Hanson DA, Teitelbaum R, Dewan P, Niazi KR, Froelich CJ, Ganz T, Thoma-Uszynski S, Melian A, Bogdan C, et al. 1998. An antimicrobial activity of cytolytic T cells mediated by granulysin. Science 282: 121-125.

StopTBPartnership, WHO. 2011. The global plan to stop TB 2011-2015.

Tameris MD, Hatherill M, Landry BS, Scriba TJ, Snowden MA, Lockhart S, Shea JE, McClain JB, Hussey GD, Hanekom WA, et al. 2013. Safety and efficacy of MVA85A, a new tuberculosis vaccine, in infants previously vaccinated with BCG: A randomised, placebo-controlled phase 2b trial. Lancet 381: 1021-1028.

Tolderlund K. 1952. Preliminary report of laboratory investigations on the effect of light on BCG vaccine. Acta Pathol Microbiol Scand Suppl 93: 299-307.

UNAIDS, WHO. 2013. Global Report: UNAIDS report on the global AIDS epidemic 2013. WHO, Geneva.

van Dissel JT, Arend SM, Prins C, Bang P, Tingskov PN, Lingnau K, Nouta J, Klein MR, Rosenkrands I, Ottenhoff TH, et al. 2010. Ag85B-ESAT-6 adjuvanted with IC31 promotes strong and long-lived Mycobacterium tuberculosis specific $\mathrm{T}$ cell responses in naive human volunteers. Vaccine 28: 3571-3581.

Verreck FA, Vervenne RA, Kondova I, van Kralingen KW, Remarque EJ, Braskamp G, van der Werff NM, Kersbergen A, Ottenhoff TH, Heidt PJ, et al. 2009. MVA.85A boosting of BCG and an attenuated, phoP deficient M. tuberculosis vaccine both show protective efficacy against tuberculosis in rhesus macaques. PLoS ONE 4: e5264.

von Reyn CF, Mtei L, Arbeit RD, Waddell R, Cole B, Mackenzie T, Matee M, Bakari M, Tvaroha S, Adams LV, et al. 2010. Prevention of tuberculosis in Bacille CalmetteGuérin-primed, HIV-infected adults boosted with an inactivated whole-cell mycobacterial vaccine. AIDS 24: 675-685.

Walker KB, Brennan MJ, Ho MM, Eskola J, Thiry G, Sadoff J, Dobbelaer R, Grode L, Liu MA, Fruth U, et al. 2010. The second Geneva Consensus: Recommendations for novel live TB vaccines. Vaccine 28: 2259-2270.

Wang J, Thorson L, Stokes RW, Santosuosso M, Huygen K, Zganiacz A, Hitt M, Xing Z. 2004. Single mucosal, but not parenteral, immunization with recombinant adenoviral-based vaccine provides potent protection from pulmonary tuberculosis. J Immunol 173: 6357-6365. 
Novel Vaccination Strategies against TB

Weiner J, Kaufmann SHE. 2014. Recent advances towards tuberculosis control: Vaccines and biomarkers. J Intern Med 275: 467-480.

Weiner J, Maertzdorf J, Kaufmann SH. 2013. The dual role of biomarkers for understanding basic principles and devising novel intervention strategies in tuberculosis. Ann NY Acad Sci 1283: 22-29.

Weinrich Olsen A, van Pinxteren LA, Meng Okkels L, Birk Rasmussen P, Andersen P. 2001. Protection of mice with a tuberculosis subunit vaccine based on a fusion protein of antigen 85B and ESAT-6. Infect Immun 69: 2773-2778.

White AD, Sibley L, Dennis MJ, Gooch K, Betts G, Edwards N, Reyes-Sandoval A, Carroll MW, Williams A, Marsh PD, et al. 2013. Evaluation of the safety and immunogenicity of a candidate tuberculosis vaccine, MVA85A, de- livered by aerosol to the lungs of macaques. Clin Vaccine Immunol 20: 663-672.

WHO. 2013. Global tuberculosis report 2013. WHO, Geneva. Woodworth JS, Behar SM. 2006. Mycobacterium tuberculosis-specific $\mathrm{CD}^{+}{ }^{+} \mathrm{T}$ cells and their role in immunity. Crit Rev Immunol 26: 317-352.

Yang XY, Chen QF, Li YP, Wu SM. 2011. Mycobacterium vaccae as adjuvant therapy to anti-tuberculosis chemotherapy in never-treated tuberculosis patients: A metaanalysis. PLoS ONE 6: e23826.

Zheng J, Liu L, Wei C, Leng W, Yang J, Li W, Wang J, Jin Q. 2012. A comprehensive proteomic analysis of Mycobacterium bovis bacillus Calmette-Guérin using high resolution Fourier transform mass spectrometry. J Proteomics 77: $357-371$. 


\title{
$\&_{\mathrm{CSH}}^{\infty} \&$ Cold Spring Harbor

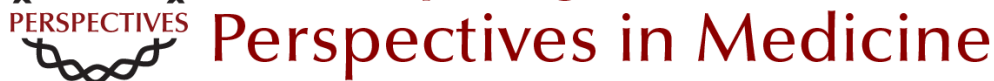

\section{Novel Vaccination Strategies against Tuberculosis}

\author{
Peter Andersen and Stefan H.E. Kaufmann \\ Cold Spring Harb Perspect Med 2014; doi: 10.1101/cshperspect.a018523
}

Subject Collection Tuberculosis

\section{Transmission and Institutional Infection Control of Tuberculosis Edward A. Nardell \\ Innate and Adaptive Cellular Immune Responses to Mycobacterium tuberculosis Infection Katrin D. Mayer-Barber and Daniel L. Barber}

Tuberculosis Comorbidity with Communicable and Noncommunicable Diseases

Matthew Bates, Ben J. Marais and Alimuddin Zumla

Host-Directed Therapies for Tuberculosis David M. Tobin

Immunity and Immunopathology in the

Tuberculous Granuloma Antonio J. Pagán and Lalita Ramakrishnan

Tuberculosis Drug Development: History and Evolution of the Mechanism-Based Paradigm? Sumit Chakraborty and Kyu Y. Rhee

Genetic Approaches to Facilitate Antibacterial Drug Development Dirk Schnappinger

The Tuberculosis Drug Discovery and Development Pipeline and Emerging Drug Targets Khisimuzi Mdluli, Takushi Kaneko and Anna Upton
Clinical Aspects of Adult Tuberculosis Robert Loddenkemper, Marc Lipman and Alimuddin Zumla

Advances in Diagnostic Assays for Tuberculosis Stephen D. Lawn

Diagnosis and Management of Latent Tuberculosis Infection

Laura Muñoz, Helen R. Stagg and Ibrahim Abubakar

Mycobacterial Growth Iria Uhía, Kerstin J. Williams, Vahid Shahrezaei, et al.

Multidrug-Resistant Tuberculosis and Extensively

Drug-Resistant Tuberculosis

Kwonjune J. Seung, Salmaan Keshavjee and Michael L. Rich

The Mycobacterial Cell Wall--Peptidoglycan and Arabinogalactan

Luke J. Alderwick, James Harrison, Georgina S. Lloyd, et al.

Tuberculosis and HIV Coinfection Judith Bruchfeld, Margarida Correia-Neves and Gunilla Källenius

Imaging in Tuberculosis Jamshed B. Bomanji, Narainder Gupta, Parveen Gulati, et al.

For additional articles in this collection, see http://perspectivesinmedicine.cshlp.org/cgi/collection/ 